Arq. Bras. Med. Vet. Zootec., v.68, n.2, p.327-335, 2016

\title{
Optimizing the transport of porcine semen: a proposal for Brazil
}

\author{
[Otimizar o transporte do sêmen suíno: uma proposta para o Brasil] \\ C.L.Á. Silva ${ }^{1}$, J.M. Silva Filho², M.S. Palhares ${ }^{2}$, G.S. Machado ${ }^{3}$, M.P. Moraes ${ }^{3}$, \\ N.M. Rocha ${ }^{1}$, L.E. Carvalho ${ }^{1}$, R. Rossi ${ }^{1}$
${ }^{1}$ Aluno de pós-graduação - Escola de Veterinária - Universidade Federal de Minas Gerais - Belo Horizonte, MG
${ }^{2}$ Escola de Veterinária - UFMG - Belo Horizonte, MG \\ ${ }^{3}$ Médico veterinário autônomo
}

\begin{abstract}
Semen from the first $15 \mathrm{~mL}$ of the ejaculate (P1) obtained from two boars $(30 \mathrm{~mL})$ was diluted in glycineegg yolk extender, cooled at $5^{\circ} \mathrm{C}$ in a special container and rediluted in standard doses of $3 \times 10^{9}$ mobile spermatozoa after $12 \mathrm{~h}$ of storage. Semen was also stored up to $24 \mathrm{~h}$ after redilution. The physical characteristics of the semen were evaluated at different storage periods (fresh, $0 \mathrm{~h}, 12 \mathrm{~h}$, rediluted, $24 \mathrm{~h}$, and 36h). The reproductive performance of the boars and their fertility regarding the insemination of primiparous sows were also determined. Two treatments were used: T1-15B sows inseminated with semen originated from hyperconcentrated heterospermic doses $\left(15 \times 10^{9}\right.$ mobile spermatozoa per dose $)$, rediluted after $12 \mathrm{~h}$ of storage at $5^{\circ} \mathrm{C}$ for standard doses of $3 \times 10^{9}$ mobile spermatozoa per dose and stored at $5^{\circ} \mathrm{C}$ up to $24 \mathrm{~h}$ after redilution $(\mathrm{n}=10)$; T2-3B sows inseminated with standard heterospermic doses $\left(3 \times 10^{9}\right.$ mobile spermatozoa per dose), stored at $5^{\circ} \mathrm{C}$ up to $36 \mathrm{~h}$ after semen collection $(\mathrm{n}=10)$. There was no effect $(\mathrm{P}>0.05)$ of treatments on the spermatic motility, even though a pronounced decrease $(\mathrm{P}>0.05)$ of their values at $12 \mathrm{~h}$ of storage was recorded. However, they remained higher than $70 \%$ until $36 \mathrm{~h}$. There was effect of treatments on spermatic vigour at $0 \mathrm{~h}(\mathrm{P}<0.05)$, when $\mathrm{T} 1-15 \mathrm{~B}$ vigour was higher. There was also effect of the storage period for both treatments with a progressive decrease throughout $36 \mathrm{~h}$ of storage, although the differences were not always significant. Pregnancy rates $(90 \%)$ and the number of total farrowed piglets $(15,11-\mathrm{T} 1-15 \mathrm{~B} ; 13,44-\mathrm{T} 2-3 \mathrm{~B})$ did not differ $(\mathrm{P}>0.05)$ between the treatments. It was concluded that the semen hyperconcentration of 15 billion of mobile spermatozoa per dose, stored at $5^{\circ} \mathrm{C}$ for $12 \mathrm{~h}$, did not result in drawbacks considering the physical characteristics of the semen, maintaining the pregnancy rates and prolificacy of the inseminated sows.
\end{abstract}

Keywords: swine, fractioned collection, cooling, transport

\section{RESUMO}

Os primeiros $15 \mathrm{~mL}$ do ejaculado (P1) de dois varrões foram coletados (30mL) e diluídos em diluidor glicina-gema de ovo, resfriados a $5^{\circ} \mathrm{C}$ em contêiner especial e rediluídos para doses padrão de $3 \times 10^{9}$ espermatozoides (sptz) móveis, após 12 horas de armazenamento. Além disso, foram armazenados por até 24 horas após a rediluição, sendo as características físicas avaliadas em diferentes períodos de estocagem (fresco, zero hora, 12h, Red12h, $24 \mathrm{~h}$ e 36h) e a fertilidade avaliada por meio de fêmeas primíparas inseminadas. Foram realizados dois tratamentos: T1-15B: porcas inseminadas com sêmen de doses heterospérmicas hiperconcentradas $\left(15 \times 10^{9} \mathrm{sptz}\right.$ móveis/dose), rediluídas após 12 horas de armazenamento a $5^{\circ} \mathrm{C}$ para doses padrão de $3 \times 10^{9}$ sptz móveis/dose, e armazenadas a $5^{\circ} \mathrm{C}$ por até 24 horas após a rediluição $(n=10)$; T2-3B: porcas inseminadas com doses heterospérmicas padrão $\left(3 \times 10^{9}\right.$ sptz móveis/dose), armazenadas a $5^{\circ} \mathrm{C}$ por até 36 horas após coleta. Não houve efeito (P>0.05) dos tratamentos sobre a motilidade espermática e, embora tenha ocorrido queda $(P<0.05)$ às 12 horas, a motilidade foi superior a $70 \%$ durante as 36 horas de armazenamento. Houve efeito $(P<0.05)$ dos

Recebido em 20 de setembro de 2014

Aceito em 3 de dezembro de 2015

*Autor para correspondência (corresponding author)

E-mail: silvafilhojm@gmail.com 
tratamentos no tempo zero hora quanto ao vigor espermático, sendo E1T1-15B superior. Além disso, houve efeito do período de estocagem para os dois tratamentos, com queda progressiva do vigor ao longo das 36 horas, embora nem sempre as diferenças tenham sido significativas. As taxas de gestação (90\%) e o número total de leitões nascidos (15, 11 - T1-15B; 13, $44-T 2-3 B)$ não diferiram $(P>0.05)$ entre os tratamentos. Concluiu-se que a hiperconcentração do sêmen para $15 \times 10^{9}$ sptz móveis/dose, armazenado a $5^{\circ} \mathrm{C}$ por 12 horas não resultou em prejuízos quanto à manutenção das características físicas do sêmen e ao desempenho reprodutivo dos varrões, sendo capaz de manter a taxa de gestação e a prolificidade das fêmeas inseminadas.

Palavras-chave: suíno, coleta fracionada, resfriamento de sêmen, transporte de sêmen

\section{INTRODUCTION}

Artificial insemination in swineherds in Brazil is mostly done with semen from the artificial insemination center of the farm, so each farm has its own semen production system. One limitation for the transportation of insemination doses in Brazil, as in other tropical countries with huge territorial extension, is the distances and the usual use of semen cooled to $15^{\circ} \mathrm{C}$ to $18^{\circ} \mathrm{C}$, temperatures that do not completely interrupt the sperm metabolism and bacterial growth, decreasing semen longevity (Weitze, 1990). There is the necessity to develop semen cooling protocols which include the use of semen extenders that guarantee good results even when the storing/transport involves longer distances and storage time at temperatures below $15^{\circ} \mathrm{C}$ (Okere, 2001).

To enable semen transportation in Brazil, Roner et al. (2006) developed a container for cooling and transporting swine semen at $17^{\circ} \mathrm{C}$ to $5^{\circ} \mathrm{C}$, according to the transportation distance. This container is made of styrofoam blocks and is able to passively cool 12 inseminating doses of $100 \mathrm{~mL}$. As it is not an expensive container, the farms are able to use it only once and discard it for sanitary reasons. However, this container can only transport and cool 12 doses, demanding the use of a large number of containers per farm.

Desjardins and Hafs (1962) proposed the storage of hyperconcentrated semen doses, as a way of reducing the costs of storage and transportation, keeping bovine semen at $5^{\circ} \mathrm{C}$ for $2-3$ days after thawing. In addition, Rodriguez-Martinez et al. (2005) showed that the spermatozoa found in the first $10-15 \mathrm{~mL}$ of the sperm rich fraction of the semen (named P1) are more resistant to laboratorial manipulation during the cooling and freezing protocol. Thereby, the P1 could be the portion of choice when performing semen collection for cooling protocols beneath $15^{\circ} \mathrm{C}$ and for freezing the semen to be stored for longer times. In 2010 , Alkmin used the first $15 \mathrm{~mL}$ of the sperm rich fraction and proved that the use of this portion for cooling protocols provides good fertility results.

In this sense, the aim of this work was to optimize the use of the container for transportation of swine semen through overconcentration of the insemination doses to 150 millions of spermatozoa $/ \mathrm{mL}$ $\left(15 \times 10^{9} / 100 \mathrm{~mL}\right)$, using semen from P1 diluted in glycine-egg yolk extender (GEY) (Foote, 2002). The semen from the P1 was stored overconcentrated at $5^{\circ} \mathrm{C}$ for 12 hours before being rediluted to standard doses of $3 \times 10^{9}$ spermatozoa at $100 \mathrm{~mL}$. In this way, we aimed to propose a new protocol for cooling, storing and transporting swine semen that could be used routinely in Brazilian farms.

\section{MATERIAL AND METHODS}

The experiment was done at Fazenda Miunça, located near Brasília, Distrito Federal, Brazil, and it was performed from November 2010 to July 2011.

Twenty-four ejaculates from nine boars were used: three Large White boars and six Landrace boars, all older than 12 months. For the inseminations, 20 primiparous DB-25 ${ }^{\circledR}$ sows were used; they were randomly distributed between the two treatments described below:

Treatment 1 (T1-15B): The insemination doses came from overconcentrated doses produced from the first $15 \mathrm{~mL}(\mathrm{P} 1)$ of the ejaculate from two boars. The $15 \mathrm{~mL}$ from the first boar were pre-diluted in $30 \mathrm{~mL}$ of GEY extender (Foote, 2002) and then kept in a water bath at $36^{\circ} \mathrm{C}$. The $15 \mathrm{~mL}$ (P1) from the second boar were then 
added to the $45 \mathrm{~mL}$ in the water bath, resulting in a pre-dilution rate of $1: 1$. The semen doses to be cooled were prepared after heterospermic prediluted semen concentration evaluation. The final doses containing 15 billion spermatozoa were cooled to $5^{\circ} \mathrm{C}$ in the container. After 12 hours of storage, these doses were rediluted to standard doses of 3 billion of mobile spermatozoa per insemination dose. After the redilution, the doses were stored at $5^{\circ} \mathrm{C}$ for up to 36 hours after the semen collection. The sows were inseminated after the redilution to $3 \times 10^{9}$ of mobile spermatozoa $(n=10)$.

Treatment 2 (T2-3B): The insemination doses came from the first $15 \mathrm{~mL}(\mathrm{P} 1)$ of the ejaculate from two boars, diluted in GEY extender, producing doses with $3 \times 10^{9}$ spermatozoa in $100 \mathrm{~mL}$. The doses were then cooled to $5^{\circ} \mathrm{C}$ in the container, and were stored for up to 36 hours after the semen collection $(\mathrm{n}=10)$.

The semen was collected using the gloved hand technique (Hancock and Howell, 1959), in plastic falcon tubes with $50 \mathrm{~mL}$ capacity, completely dry and sterilized, kept in store at $36^{\circ} \mathrm{C}$. Coupled with the tube, a plastic funnel covered with a paper filter for swine semen was used to facilitate semen collection from the P1. Immediately after the collection, the semen motility and vigor were evaluated using an optic microscopy at 100x and 400x magnification. The semen from the first male (M1) was then prediluted in $30 \mathrm{~mL}$ GEY extender and kept in a water bath at $36^{\circ} \mathrm{C}$. As soon as the semen from the second male (M2) was collected and evaluated for motility and vigor, the $15 \mathrm{~mL}$ of semen $(\mathrm{P} 1)$ were added to the diluted semen plus GEY extender in the water bath, resulting in $60 \mathrm{~mL}$ of semen plus extender $(15 \mathrm{~mL} \mathrm{M1+}$ $15 \mathrm{~mL} \mathrm{M} 2+30 \mathrm{~mL}$ GEY $=60 \mathrm{~mL}$ ) of pre-diluted semen at a rate of $1: 1$. After the pre-dilution, the heterospermic pre-diluted semen was evaluated to check the concentration, motility and vigor. The concentration was calculated using Neubauer chamber, at a dilution rate of 1:1000, to determine the number of spermatozoa per $\mathrm{mL}$. After the number of live spermatozoa per $\mathrm{mL}$ (concentration and motility considered) was determined, the volume of semen to be added to the plastic tubes for each treatment was determined to be 15 billion (T1-15B) or 3 billion (T2-3B). Immediately after the insemination doses of $100 \mathrm{~mL}$ were prepared and filled, the semen was submitted to the cooling protocol at $5^{\circ} \mathrm{C}$ in the special container (Roner et al., 2006). The cooled semen was also evaluated every 12 hours to assess the motility and vigor, and the analyses were made with an optic microscope with 100x and 400x magnification. To perform the analyses of the cooled semen, a sample of $1.5 \mathrm{~mL}$ was collected in a micro tube, and heated in a water bath at $37^{\circ} \mathrm{C}$ for 10 minutes before semen evaluation.

The motility was expressed through percentage $(0-100 \%)$. To evaluate the sperm vigor we used a subjective grade of 0 to 5 (0-immovable, and 5higher velocity). The physical characteristics of the semen were evaluated in different storage times: fresh - semen immediately after predilution in GEY; $0 \mathrm{~h}$ - semen immediately after treatment doses preparation; $12 \mathrm{~h}$ - semen after 2 hours of storage at $5^{\circ} \mathrm{C}$; Rediluted - semen evaluated immediately after the redilution, after 12 hours of storage at $5^{\circ} \mathrm{C}$ with $15 \times 10^{9}$ sperm/mL (only for T1); $24 \mathrm{~h}-$ semen evaluation after 24 hours of storage at $5^{\circ} \mathrm{C}$ (T2), and 12 hours after the redilution (T1); 36h - semen evaluation after 36 hours of storage at $5^{\circ} \mathrm{C}(\mathrm{T} 2)$ and $24 \mathrm{~h}$ after the redilution (T1).

Semen redilution (T1-15B) was performed after 12 hours of hyperconcentrated storage at $5^{\circ} \mathrm{C}$. Five hours before the redilution, the necessary volume of GEY extender was prepared and maintained inside the fridge at $15^{\circ} \mathrm{C}$. One hour and 30 minutes before the predicted time for redilution, the extender was added to plastic insemination tubes, and maintained inside the cooler desk, previously programed to $4.3^{\circ} \mathrm{C}$. The insemination plastic tubes filled with extender and the pipettes were also put in the cooler desk. In this way, at the moment of redilution, as soon as the extender reached the same temperature of the semen, the container containing the overconcentrated semen doses was also taken to the cooler desk.

Immediately after the overconcentrated semen evaluation, the plastic insemination tube was removed from the container, and the extender and semen temperatures were evaluated; when the temperatures were equal, the redilution was done. The hyperconcentrated semen was carefully homogenized with a $20 \mathrm{~mL}$ glass pipette and a new pipette was used for filling the insemination bags with the correspondent 
volume of hyperconcentrated semen to achieve the final concentration of $3 \times 10^{9}$ spermatozoa $/ 100 \mathrm{~mL}$. At the end of the redilution, a sample of the rediluted semen was evaluated.

Heat detection was done twice a day with the use of a mature boar. The insemination protocol was the same for both treatments. The females detected as in heat in the morning were inseminated at night on the same day, and the females that were detected as in heat in the afternoon were inseminated in the morning of the next day. Insemination interval averaged 12 hours until the end of heat. The insemination technique was traditional, with intracervical deposition of the semen.

The pregnancy diagnosis was made using heat detection with a mature boar, from the $17^{\text {th }}$ until the $30^{\text {th }}$ day after the last insemination. The pregnancy rate was evaluated through the rate of non-heat recurrence. Birth rate was evaluated for each treatment, and also the litter characteristics (total born, born alive, stillbirth, mummified).

The experimental design was completely randomized. The sows were distributed in each treatment by drawing. The dataset analyses were performed using SAS (SAS Inst. Inc., Cary, NC), and the proportional data (pregnancy rate, mortality rate, heat recurrence rate and farrowing rate) were evaluated by frequency distribution and The Qui-Square Test. The quantitative data (litter characteristics) were analyzed using the GLM procedure; the averages were compared using the SNK (Student Newman Keuls) for three or more means, or using the Student's t-test, for two means.

The data concerning the physical characteristics of the semen and reproductive performance of the sows were analyzed using the Student's t-test. Whenever necessary, the data was transformed $\left(\operatorname{arcsen} \mathrm{V}_{\%}\right)$. The characteristics that were subjectively evaluated, like semen vigor, were analyzed using the non-parametric approach with the Wilcoxon test.

\section{RESULTS AND DISCUSSION}

There was no effect of the treatment on semen motility $(\mathrm{P}>0.05)$, although there was an effect $(\mathrm{P}<0.05)$ of the time of semen storage (Tab. 1).

The sperm motility observed on the fresh semen immediately after the collection and pre-diluted 1:1 was the same for both treatments, due to the fact that the semen from both treatments came from the same ejaculates. This could also explain the close values of motility observed $(\mathrm{P}>0.05)$ in both treatments at $0 \mathrm{~h}$, corresponding to the moment when the hyperconcentrated doses (T115B) and the standard doses (T2-3B) were prepared, before the cooling in the container (Tab. 1).

Table 1. Sperm motility on semen diluted, cooled and stored in a special container

\begin{tabular}{cllllll}
\hline \multirow{2}{*}{ Treatment } & \multicolumn{5}{c}{ Evaluation period } \\
\cline { 2 - 7 } & Fresh & Zero hours & 12 hours & Redilution & 24 hours & 36 hours \\
\hline T1-15B (\%) & $82.27 \pm 1.50$ & $81.82 \pm 1.50$ & $73.64 \pm 1.50$ & $73.64 \pm 1.50$ & $71.82 \pm 1.50$ & $70.71 \pm 1.88$ \\
T2 -3B (\%) & $82.27 \pm 1.50$ & $80.91 \pm 1.50$ & $75.00 \pm 1.50$ & & $72.27 \pm 1.50$ & $70.71 \pm 1.88$ \\
Total & $82.27 \pm 1.04 \mathrm{a}$ & $81.36 \pm 1.04 \mathrm{a}$ & $74.32 \pm 1.04 \mathrm{~b}$ & $73.73 \pm 1.55 \mathrm{~b}$ & $72.05 \pm 1.04 \mathrm{~b}$ & $70.71 \pm 1.31 \mathrm{~b}$ \\
\hline
\end{tabular}

Means in same line with different letters are different $(\mathrm{P}<0.05)$

There was a sharp drop in sperm motility $(\mathrm{P}<0.05)$ at $12 \mathrm{~h}$ of storage in both treatments. However, the motility stabilized after this time, and the values observed were higher than $70 \%$ until 36 hours. Sperm vigor was influenced $(\mathrm{P}<0.05)$ by the treatment and the storage time. However, treatment effect was observed only at $0 \mathrm{~h}$, when the values from $\mathrm{T} 1-15 \mathrm{~B}$ were higher than observed in the T2-3B (Tab. 2).

Sperm vigor values were sustained without any significant changes $(\mathrm{P}>0.05)$ during the first 12 hours of storage, in both treatments. However, at 24 hours of storage, sperm vigor decreased in relation to the observed at $0 \mathrm{~h}$ for the $\mathrm{T} 1-15 \mathrm{~B}$, and was reduced up to 36 hours, despite the fact that the values did not decrease after the redilution until 36 hours. Besides, the vigor values observed at 24 and at 36 hours were lower $(\mathrm{P}<0.05)$ than the ones observed in fresh semen. In general, sperm vigor showed progressive reduction in both treatments during the storage time until the 36 hours, although not all differences were significant. 
Optimizing the transport...

Table2: Sperm vigor on semen diluted, cooled and stored in a special container

\begin{tabular}{|c|c|c|c|c|c|c|}
\hline \multirow{2}{*}{ Treatments } & \multicolumn{6}{|c|}{ Evaluation period } \\
\hline & Fresh & Zero hours & 12 hours & Redilution & 24 hours & 36 hours \\
\hline $\mathrm{T} 1-15 \mathrm{~B}$ & $3.45 \pm 0.15 \mathrm{abA}$ & $3.73 \pm 0.15 \mathrm{aA}$ & $3.50 \pm 0.15 \mathrm{abA}$ & $3.32 \pm 0.15 \mathrm{abc}$ & $3.23 \pm 0.15 \mathrm{bcA}$ & $3.00 \pm 0.19 \mathrm{cA}$ \\
\hline $\mathrm{T} 2-3 \mathrm{~B}$ & $3.45 \pm 0.15 \mathrm{aA}$ & $3.23 \pm 0.15 \mathrm{abB}$ & $3.36 \pm 0.15 \mathrm{aA}$ & - & $2.91 \pm 0.15 \mathrm{cA}$ & $2.71 \pm 0.19 b c A$ \\
\hline Total & $3.45 \pm 0.11$ & $3.48 \pm 0.11$ & $3.43 \pm 0.11$ & $3.32 \pm 0.15$ & $3.07 \pm 0.11$ & $2.86 \pm 0.13$ \\
\hline
\end{tabular}

Means in the same line with different letters are different $(\mathrm{P}<0.05)$.

Means in the same column with different letters are different $(\mathrm{P}<0.05)$.

The treatments were also evaluated through the insemination of 20 sows. The data related to heat duration, fertility and prolificacy of the females is shown in Tab. 3.

The WOI did not differ in both treatments $(\mathrm{P}>0.05)$. However, heat duration was different
$(\mathrm{P}<0.05)$. It was higher for the sows on $\mathrm{T} 1-15 \mathrm{~B}$, possibly because of the numerically smaller WOI. Regardless of the heat duration, the mean number of inseminations was not different $(\mathrm{P}>0.05)$ between the treatments (Tab. 3).

Table 3. Heat characteristics, fertility and prolificacy of the sows inseminated in both treatments

\begin{tabular}{lcc}
\hline \multirow{2}{*}{ Variables } & \multicolumn{2}{c}{ Treatments } \\
\cline { 2 - 3 } Number of sows & $\mathrm{T} 1-15 \mathrm{~B}$ & $\mathrm{~T} 2-3 \mathrm{~B}$ \\
Parity & 10 & 10 \\
Weaning to Oestrus Interval (WOI/hours) & 1 & 1 \\
Heat duration (hours) & $94.05 \pm 3.45$ & $101.26 \pm 2.41$ \\
Number of inseminations (mean \pm SD) & $64.70 \pm 2.79^{\mathrm{a}}$ & $55.95 \pm 2.93^{\mathrm{b}}$ \\
Pregnancy rate (\%) & $3.90 \pm 0.10$ & $3.60 \pm 0.16$ \\
Farrowing rate (\%) & $90 \%(9 / 10)$ & $90 \%(9 / 10)$ \\
Number of piglets born alive & $90 \%(9 / 10)$ & $80 \%(8 / 10)^{*}$ \\
Number of stillborn & $12.44 \pm 1.24$ & $12.63 \pm 1.54^{*}$ \\
Number of mummified & $1.11 \pm 0.39$ & $0.75 \pm 0.41$ \\
Total number of piglets born & $1.56 \pm 1.31$ & $0.22 \pm 0.15$ \\
\hline
\end{tabular}

Means in the same line with different letters are different $(\mathrm{P}<0.05)$

${ }^{*}$ The data related to the number of piglets born alive concerns eight of the nine pregnant females, due to the fact that one sow had an abortion. However, these piglets were counted and included in the total number of piglets born and number of mummified.

The pregnancy and farrowing rates, as well as the litter characteristics, were not influenced by the treatments $(\mathrm{P}>0.05)$. From the 20 inseminated sows, only two were not pregnant, one in the T1-15B and one in the T2-3B. Thus, the pregnancy rate was $90 \%$ in both treatments. One of the sows belonging to the T2-3B treatment had an abortion at 82 days of pregnancy, so that only 8 sows farrowed, and pregnancy rate was $80 \%$. The total number of piglets born and the number of piglets born alive in $\mathrm{T} 1-15 \mathrm{~B}$ did not differ from that observed in the T2-3B (control group), as well as the number of stillborn and mummified piglets (Tab. 3).

\section{DISCUSSION}

The observed P1 motility in this experiment $(82.27 \%)$ is close to the results of Saravia et al. (2008), of $86.2 \%$ after fractionated semen collection and dilution in BTS. However, Alkmin (2010), working with the P1, observed a sperm motility of $74.5 \%$ for fresh semen, which is lower than the values observed in this experiment. When comparing the sperm motility of the P1 with the remainder of the ejaculate, the author observed smaller values always in the P1, although without significant differences $(\mathrm{P}>0.05)$ between the two portions of the ejaculate concerning farrowing rate and litter 
characteristics. On the other hand, RodriguezMartinez et al. (2005), after the fractionated semen collection, cooling to $15^{\circ} \mathrm{C}$, and then cooling to $5^{\circ} \mathrm{C}$, observed higher motility values for $\mathrm{P} 1$ in relation to the remaining ejaculate after thawing.

Siqueira (2011) observed motility reduction $(\mathrm{P}<0.05)$ after 12 hours of storage in hyperconcentrated doses containing 6,9 or 12 billion spermatozoa in $100 \mathrm{~mL}$ from the total ejaculate and diluted in GEY, as observed in the present experiment. The author observed mean motility values for doses containing 3, 6 and 9 billion spermatozoa, after 12 hours of storage of $76.25 \%$, and for doses containing 12 billion sperm $/ 100 \mathrm{~mL}$ the motility was $73.33 \%$. All these values are close to the motility values observed in this experiment for the same time of storage $(74.32 \%$ at $12 \mathrm{~h})$. Thus, it is clear that the storage of the hyperconcentrated semen for 12 hours in GEY containing 12 or 15 billion $/ 100 \mathrm{~mL}$, diluted in GEY (Foote, 2002), and cooled at $5^{\circ} \mathrm{C}$ can be used, since the seminal quality is maintained between 36 and 60 hours of storage. However, Alkmin (2010), despite not working with hyperconcentrated semen doses, observed significant $(\mathrm{P}<0.05)$ and continued reduction of the motility during 72 hours of storage, and at 36 hours the motility was already $55 \%$.

Saravia et al. (2008) observed sperm motility P1 semen diluted in Lactose-Egg Yolk -Glycerol extender and cooled at $5^{\circ} \mathrm{C}$, higher than the motility observed in this experiment $(91.6 \%$ vs $74.3 \%$ ), however, the storage time was shorter than 12 hours.

Regarding sperm vigor, the observed mean value in this experiment for fresh semen pre-diluted in GEY (3.45) was inferior to the mean value observed by Alkmin (2010) in fresh non-diluted semen (4.70).

The T1-15B treatment showed a sharp decline $(\mathrm{P}<0.05)$ at 24 hours of storage when compared to the one observed at $0 \mathrm{~h}$ (3.73 vs 3.23). Similarly, Alkmin (2010) also observed decline $(\mathrm{P}<0.05)$ of sperm vigor at 24 hours of storage in relation to $0 \mathrm{~h}(3.55$ vs 3.75$)$. However, the redilution did not affect $(\mathrm{P}>0.05)$ sperm vigor in this experiment. Siqueira (2011) observed a reduction in sperm vigor values at 24 hours of storage at $5^{\circ} \mathrm{C}$ in semen doses containing 6 and 9 billion of spermatozoa, and after 36 hours for doses with 12 billion of spermatozoa in $100 \mathrm{~mL}$, which differ from the observations in this experiment for $\mathrm{T} 1-15 \mathrm{~B}$, which did not show a reduction in sperm vigor at 36 hours of storage in relation to 24 hours.

According to Silveira and Lais (1999), semen with vigor 3 to 5 has higher fertilizing. Concerning semen motility, reduction of reproductive performance in boars was only observed with motility below 60\% (Flowers, 1997). The decrease of motility and of sperm vigor during storage is related to in vitro aging of the spermatozoa (Johnson et al., 2000) and is independent of the semen extender used. However, semen storage at $5^{\circ} \mathrm{C}$ reduces the metabolic activity of the spermatozoa and, consequently, reduces the production of the catabolites, which can contribute for reduction of sperm viability.

During cooling, storing, freezing and thawing, a lot of the spermatozoa are injured and die, which leads to production of hydrogen peroxide $\left(\mathrm{H}_{2} \mathrm{O}_{2}\right)$, even in lower temperatures. However, the lypid peroxidation effects on sperm membranes due to $\mathrm{H}_{2} \mathrm{O}_{2}$ can be minimized by reducing the oxygen tension and/or by the inclusion of antioxidants in the semen diluent. Thus, it could be that the higher number of spermatozoa $/ \mathrm{mL}$ in the hyperconcentrated doses from T1-15B favored the storage of the semen by reducing the $\mathrm{O}_{2}$ tension, as proposed by Windson et al. (1993) for ram semen.

In general, both treatments maintained the values of sperm vigor above 3 for up to 12 hours of storage, and in $\mathrm{T} 1-15 \mathrm{~B}$, vigor 3 was sustained until 36 hours of storage at $5^{\circ} \mathrm{C}$. Regarding semen motility, values were higher than $70 \%$ for up to 36 hours of storage.

The mean insemination number did not differ in the two treatments $(\mathrm{P}>0.05)$ (Tab. 3). In sows, optimum fertility results can be achieved when a least one of the inseminations is done between 24 and 12 hours before ovulation (Soede et al., 1995), and in the majority of sows ovulation takes place at approximately two-thirds of the oestrus period. However, there is huge variation in the duration of oestrus between sows, ranging from less than $24 \mathrm{~h}$ to more than $96 \mathrm{~h}$, and this variation makes it difficult to predict the 
optimum time for insemination, which in turn makes it necessary to inseminate more than once during heat (Soede et al., 2000). Insemination interval is influenced by some facts, for example, the temperature of cooling and storage time. It is advisable to reduce insemination intervals when the used semen is cooled and kept in storage for longer times (Soede et al., 2000). This is the reason for the conservative insemination protocol chosen for this experiment.

Foote (2002) used semen diluted in GEY, cooled to $5^{\circ} \mathrm{C}$ and stored for 48 hours to inseminate sows. Pregnancy rate was $63 \%$ with 10.8 piglets born alive. These results are different from the ones found in this study for both treatments $(90 \%$ and $80 \%$, and 12.44 and 12.63 born alive, respectively for $\mathrm{T} 1-15 \mathrm{~B}$ and $\mathrm{T} 2-3 \mathrm{~B})$. The differences observed in these two experiments can be related to differences in the cooling rate (slower in the present experiment) or even due to genetic differences between the sows and boars used in each experiment. We should also consider that the quick genetic improvement observed in the dam lines, which has been improving the number of piglets born over the years, makes it difficult to compare studies from different times.

Working with the total ejaculate, Braga (2007) observed a pregnancy rate of $77 \%$ and total number of piglets born and born alive of 10.72 and 10.12, respectively, also using GEY diluent and semen cooled at $5^{\circ} \mathrm{C}$. On the other hand, the pregnancy rate observed by Alkmin (2010), working with $\mathrm{P} 1$, was $90 \%$ with 13.39 total piglets born and 11.82 piglets born alive. Both studies observed lower prolificacy than the observed for both treatments in this experiment. Siqueira (2011), also working with hyperconcentrated semen that was rediluted after 16 hours of storage at $5^{\circ} \mathrm{C}$, observed a pregnancy rate of $100 \%$ for semen doses containing 3 and 6 billion spermatozoa/100mL. However, for the doses with 9 and 12 billion of spermatozoa, pregnancy rate and farrowing rate were $76.9 \%$ and $75 \%$, respectively, for both concentrations. Thus, we notice that doses with concentrations closer to T1-15B (9 and 12 billion) showed lower fertility, however the storage time was shorter in this study in comparison with Siqueira (2011) (10.99h vs. 16h, respectively). Regarding the prolificacy of the females inseminated with rediluted semen from doses coming from the rediluted semen from hyperconcentrated doses containing $12 \times 10^{9}$ spermatozoa/mL, the number of total piglets born was 12.80 , and the number of piglets born alive was 12.10 .

Recently published studies indicate that the spermatozoa present in the first $10-15 \mathrm{~mL}$ of the sperm rich fraction of the boar semen, or P1, which are the first $70-100 \mathrm{~mL}$ after the prespermatic fraction, were more resistant to storage at environmental temperatures, cooling and freezing/thawing than the spermatozoa found at the remainder of the ejaculate, or P2. This higher resistance is related mostly to the qualitative and quantitative differences in the protein composition of the seminal plasma, related to spermadesin concentration, mainly heterodymer PSP-I/PSP-II (Saravia et al., 2009), which are found in smaller proportions in P1 than in P2. It is well documented that the spermatozoa from the tail of the epididymis sustain better routine freezing compared with ejaculated spermatozoa, and the P1 still contains relatively large proportions of epididymal fluid components, which could explain the better performance of the spermatozoa from P1 in comparison with the spermatozoa from P2 (Saravia et al., 2009).

Besides the seminal plasma composition, we also used semen hyperconcentration during storage before redilution and insemination. Shannon (1968) diluted the ejaculate from 20 bulls in citrate-egg yolk diluent, cooling to $5^{\circ} \mathrm{C}$ with concentrations of 125 or $200 \times 10^{6}$ spermatozoa $/ \mathrm{mL}$. According to the author, there was significant interaction between the Nitrogen saturation rate associated with the reduction in the Oxygen tension, storage time and dilution rate of the semen. Thus, the reduction in the Oxygen tension (bigger Nitrogen saturation) prevented the sperm motility from the decrease that normally follows long storage times. This protection was more pronounced in hyperconcentrated semen.

Despite the resistance against using noncommercial diluent in swine artificial insemination (AI) centers in Brazil, the responsible for these AI centers should consider that in bull artificial insemination centers all over the world, which handle thousands of doses daily, the diluent used to freeze the insemination doses also contains egg yolk, which creates the necessity of preparing it daily, as in this case. We 
can infer, with the results from Alkmin (2010) that the insemination doses diluted in GEY (Foote, 2002) showed best semen motility and vigor when compared with the doses diluted in MR- $A^{\circledR}$. Considering the challenge of maintaining the boar semen motility and fertility during storage for later use in inseminations, the use of diluents with egg yolk represents great advancements for the cooling/transportation/ storage protocols. Besides, in 1955 Roy already stated that the diluents that better preserve semen motility seem to be the ones containing glycine and egg yolk. The component of egg yolk pointed as the responsible for sperm protection is the Low Density Lipoproteins (LDL's), which attach to the sperm membrane and also to plasma seminal proteins, avoiding the cholesterol losses after ejaculation that lead to damage and sperm death.

Nowadays in Brazil most inseminations are locally done, sometimes regionally, leading to the sub utilization of boars with huge genetic value. The optimization of semen transport could reduce the genetic gap between the nucleus herds and the multipliers. The tendency is that the swine AI centers follow what has been done in bovine AI centers, becoming bigger and fewer, distributing high number of semen doses (Landsverk, 2000).

\section{CONCLUSIONS}

Altogether, the use of the fractionated semen collection ensured a smaller proportion of injured and damaged cells after cooling, hyperconcentration, redilution and storage (cooling protocol). This, together with the reduction of Oxygen tension due to higher concentration of spermatozoa per $\mathrm{mL}$ of diluted semen at $\mathrm{T} 1-15 \mathrm{~B}$, ensured the semen viability during the storage at $5^{\circ} \mathrm{C}$, before the redilution. We can then conclude that the P1 is the most suitable fraction to be collected and processed for hyperconcentrated transportation, after the dilution and cooling at $5{ }^{\circ} \mathrm{C}$, to target farms, where they can be rediluted to standard doses with 3 billion motile spermatozoa for immediate use or storage for up to 36 hours.

\section{ACKNOWLEDGEMENTS}

This work was supported by funds from Fapemig (scholarship) and the DB DanBred do Brasil company. The authors declared no potential conflicts of interest regarding the research, authorship and publication of this article.

\section{REFERENCES}

ALKMIN, V.D. Efeito da fração do ejaculado e do método de conservação sobre as características físicas do sêmen suíno e a fertilidade de fêmeas. 2010. 226f. Tese (Mestrado em Ciência Animal) - Escola de Veterinária, Universidade Federal de Minas Gerais, Belo Horizonte, MG.

BRAGA, C.S.R. Fertilidade de fêmeas suínas inseminadas com sêmen diluído e resfriado a $5^{\circ} \mathrm{C}$ ou $17^{\circ} \mathrm{C}$. 2007. 173f. Dissertação (Mestrado em Medicina Veterinária) - Escola de Veterinária, Universidade Federal de Minas Gerais, Belo Horizonte, MG.

DESJARDINS, C.; HAFS, H.D. Motility and fertility during post-thawing storage of bovine spermatozoa frozen concentrated, thawed, and re-extended. J. Dairy Sci., v.45, p.1242-1247, 1962.

FLOWERS, W.L. Management of boars for efficient semen production. J. Reprod. Fertil. Suppl., v.52, p.67-78, 1997.

FOOTE, R.H. Within-herd use of boar semen at $5^{\circ} \mathrm{C}$, with a note on electronic monitoring of oestrus. Rep. Domest. Anim., v.37, p.61-63, 2002.

HANCOCK, J.L.; HOWELL, G.J.R. The collection of boar semen. Vet. Rec., v.71, p.664$665,1959$.

JOHNSON, L.A.; WEITZE, K.F.; FISER, P. et al. Storage of boar semen. Anim. Reprod. Sci., v.62, p.143-172, 2000.

LANDSVERK, K. Packaging and distribution their impact on fertility. In: INTERNATIONAL CONFERENCE ON BOAR SEMEN PRESERVATION, 4., 1999, Beltsville, Maryland, USA. Proceedings... Lawrence: Allen, 2000. p.137-139.

OKERE, C. Impact of modern reproductive technologies in pigs on productivit. A review. In: FOCUS ON THE FUTURE CONFERENCE, 2001, Red Deer, Proceedings... Red Deer: [s.n.], 2001. p.49-65. 
RODRÍGUEZ-MARTÍNEZ, H.; SARAVIA, F.; WALLGREN, M. et al. Boar spermatozoa in the oviduct. Theriogenology, v.63, p.514-35, 2005.

RONER, M.N.B.; SILVA FILHO, J.M.; PALHARES, M.S. et al. Desenvolvimento de um sistema de resfriamento e conservação de sêmen suíno. Arq. Bras. Med. Vet. Zootec., v.58, p.78-86, 2006.

ROY, A. Storage of boar and stallion spermatozoa in glicine-egg yolk medium. Vet. Rec., v.67, p.330, 1955.

SARAVIA, F.; WALLGREN, M.; RODRÍGUEZ-MARTÍNEZ, H. Optimization of cryopreservation of boar semen in MiniFlatPacks by using a simpler protocol and a specific portion of the ejaculate. Anim. Reprod. Sci., v.43, p.181, 2008.

SARAVIA, F.; WALLGREN, M.; JOHANNISSON, A. et al. Exposure to the seminal plasma of different portions of the boar ejaculate modulates the survival of spermatozoa cryopreserved in MiniFlatPacks. Theriogenology, v.71, p.662-675, 2009.

SAS/STAT (1990) SAS Institute, Cary, NC, USA.

SHANNON, P. Advances in semen dilution. Proc. N. Z. Soc. Anim. Prod., v.28, p.23-31, 1968.
SILVEIRA, P.R.S.; LAIS, I. Curso de inseminação artificial em suínos. Concórdia: EMBRAPA Suínos e Aves, 1999. 20p.

SIQUEIRA, A.P. Efeito da concentração espermática pré-rediluição e do protocolo de resfriamento do sêmen sobre a viabilidade espermática e fertilidade de fêmeas suínas inseminadas. 2011. 380f. Tese (Doutorado em Reprodução Animal) - Escola de Veterinária, Universidade Federal de Minas Gerais, Belo Horizonte, MG.

SOEDE, N.M.; WETZELS, C.C.H.; ZONDAG, W. et al. Effects of a second insemination after ovulation on fertilization rate and accessory sperm count in sows. J. Reprod. Fertil., v.105, p.135-140, 1995.

SOEDE, N.M.; STEVERINK, D.W.B.; LANGENDIJK, P. et al. Optimized insemination strategies in swine AI. In. BOAR SEMEN PRESERVATION, 4., 2000, Beltsville. Proceedings... Beltsville: Allen Press, 2000. p.185-192.

WEITZE, K.F. Long- term storage of extended boar semen. Rep. Domest. Anim., v.1, suppl., p.23-253, 1990.

WINDSON, D.P.; WHITE, I.G.; SELLEY, M.L. et al. Effects of the lipid peroxidation product (E)-4-hidroxy-2-nonenal on ram sperm function. J. Reprod. Fertil., v.99, p.359-366, 1993. 